\title{
On Effectiveness of Growth Regulators for Presowing Seeds Treatment of Soybean
}

\author{
Eliseeva Lyudmila Valeryevna \\ Department of Agriculture and Plant \\ Chuvash State Agricultural Academy \\ Cheboksary, Russia
}

\author{
Kayukova Olga Varsanofieva \\ Department of Agriculture and Plant \\ Chuvash State Agricultural Academy \\ Cheboksary, Russia
}

\author{
Eliseev Ivan Petrovich \\ Department of Agriculture and Plant \\ Chuvash State Agricultural Academy \\ Cheboksary, Russia \\ Mefodiev Georgy Anatolyevich \\ Department of Agriculture and Plant \\ Chuvash State Agricultural Academy \\ Cheboksary, Russia
}

Filippova Svetlana Veniaminovna

Department of Agriculture and Plant

Chuvash State Agricultural Academy

Cheboksary, Russia

\begin{abstract}
To increase the acreage of soybeans, it is necessary to introduce agrotechnical methods that promote its earlier maturation and increase the productivity of plants. The object of research was the soybean variety SibNIIK 315, the seeds of which were processed before sowing with Ekopin, Lignohumate and Seedlings. Processing with Ekopin and Lignohumate growth regulators contributed to the emergence of seedlings 2-4 days earlier than control, flowering began 3-4 days earlier and, in general, their use contributed to accelerating the ripening of soybeans. At the same time the vegetation period time was reduced by 5-7 days compared with the control. On the average, the growing season in the control variant was 106 days, in the variant with the use of Ekopin - 97 days, Lignohumate - 101 days, Seedlings - 103 days. The height of soybean plants differed little in terms of options. On average, it was $68.61 \mathrm{~cm}$ over the years of research in the control group, in the variants with Ekopin, Lignohumate and Seedlings $-72.52 \mathrm{~cm}, 69.35 \mathrm{~cm}$ and $71.8 \mathrm{~cm}$, respectively. On the average, over three years of research, the highest yield of soybean has been obtained in the variant using the growth regulator Lignohumate $-4.63 \mathrm{t} / \mathrm{ha}$. A little less $-4.39 \mathrm{t} / \mathrm{ha}$ has been obtained in the variant with the use of Ekopin. The attained results indicate the effectiveness of pre-sowing treatment of soybean seeds with Ekopin and Lignohumate growth regulators.
\end{abstract}

Keywords - soybean, growth regulators, Ekopin, Lignohumate, Seedlings

\section{INTRODUCTION}

Soybean is the most important oil-bearing-crop and leguminous crop in the world agriculture. Soybean occupies the first place among all grain legumes in the area occupied by crop in the world agriculture. However, soybean occupies significantly less space in our country.

Soy protein is well absorbed by the body. Due to this, it is brought closer to animal proteins. It is soy that is decisive in solving the problem of eliminating protein deficiency. Currently, in the territory of the Russian Federation, it is mainly cultivated in the Volga region, in the Central Black Earth Region, in the North Caucasus and the Far East. [4]

Recently, this culture has been spreading to northward of the country. However, unstable weather conditions do not always allow obtaining sufficiently high and stable yields of this crop in the Non-Chernozem zone, in particular, in the Chuvash Republic. One of the reasons for the inadequate distribution of soybean in the republic is later ripening than other legumes, as well as low productivity. The solution to this problem can be the use of special agronomic techniques, allowing reducing the growing season of soybeans, as well as increasing its yield and anti-stress resistance. [5].

Technological methods of growing crops are constantly being improved in order to bring them to fit the biological characteristics of the plant. At the same time, the proper determination of the timing and doses of the use of mineral fertilizers, plant protection products, weed, pest and disease control products, as well as microfertilizers and growth regulators, is of particular importance.

A significant reserve for increasing yields and improving the quality of grain for growing crops using intensive technologies is the use of modern, highly efficient plant growth 
stimulants. They process the seeds before sowing and spray the crops during the growing season.

The physiological effect of the use of growth regulators and micronutrients is to improve the processes of vital activity [12].

Currently, plant growth regulators are being used more and more widely in agricultural technologies, which are used both for presowing treatment of seeds and for the treatment of vegetative plants. Plant growth regulators help to increase the germination rate and seed germination energy, are able to remove the peace of growth points, prevent the stretching of seedlings of vegetables and ornamental crops, accelerate the root formation processes of cuttings and seedlings. In addition, some stimulants can increase plant immunity and resistance to unfavorable growth conditions and stressful situations, accelerate flowering, fruiting, increase yields, ensure ecological purity of the crop (prevent the accumulation of heavy metals, radionuclides, herbicides, nitrates). One of the most important properties of any growth regulators, especially humates, is the ability to absorb from the soil an excess of heavy metal ions. In the meantime, they lower the radionuclide content in cultivated crops, passing into a less digestible form for plants [1].

All this makes plant growth regulators indispensable components in the technology of cultivation of agricultural crops.

In addition, growth regulators are involved in the management of metabolism at all stages of plant life - from the development of the embryo to the full completion of the life cycle and death. Modern growth-promoting substances, created primarily on a plant-based basis, have a fairly wide range of physiological activity and are safe for the environment [7].

Yield growth using growth regulators for presowing treatment of seeds of agricultural crops has been established by numerous studies. They are of particular interest in the cultivation of such crops, the harvesting of which in production conditions is difficult due to the long growing season.

The influence of each growth stimulant specifically, it depends on the soil and climatic conditions, and the biological characteristics of culture. In addition to direct effects on growth, growth regulators have a multifunctional effect, causing a wide range of responses [15].

Currently, a large number of substances known to have a regulatory effect on plants. Interest in growth regulators are due to the fact that the new products of the third generation are created. Many effective regulators of the general stimulating effect, isolated from microorganisms, have appeared. Promising is the use of low-toxic and highly effective organosilicon compounds, as well as environmentally safe phytoregulators, whose effect is manifested when using extremely small doses of $-10 \ldots 100 \mathrm{mg} / \mathrm{ha}$ [2].

In the intensive crop sector, which depends on high yields of very good quality to ensure the income of farmers and the supply of products to the population of the country, seed dressing or planting material is now the first most economically advantageous and most environmentally safe measure of plant protection. The effectiveness and cost-effectiveness of chemical disinfectants are increased by combining them with plant growth regulators. Such technique specifically affects the growth and development of plants from germinating seedling to harvest, activates their immunity and at the same time reduces the consumption rates of disinfectants. Modern technologies should include the use of environmentally friendly biostimulants that increase yields and reduce the environmental footprint on the soil [4].

A number of studies indicate the effectiveness of growth regulators in the cultivation of soybean in order to increase the productivity of soybean plants. Thus, the presowing treatment of soybean seeds with growth regulators contributed to the acceleration of ripening, reducing the length of the growing season to 7-10 days. [2]. At the same time, growth regulators influenced the elements of the structure of the soybean crop. In particular, there was an increase in productive beans per plant, the number of seeds per plant and their size. [3]. Plants grown from seeds treated with growth regulators had a high degree of safety for harvesting, provided a significant increase in the yield of soybean seeds, on average, up to $30-35 \%$. [8]. The effectiveness of stimulating substances was noted during their treatment of vegetative plants, which primarily affected the acceleration of ripening and the increase in seed size [10].

An enormous regulatory role is played by chemicals in the life of any plant. They direct and stimulate all vital activity. The normal growth and development of the plant organism is ensured by the endogenous phytohormones, which form the plants themselves. Growth regulators are synthesized in one of the plant organs: some in young leaves, others in the apical bud, others in the roots. Then they move and stimulate the processes of growth and development. Growth regulators include auxins, gibberellins, cytokinins, ethylene, and others. Auxins are formed in the tops of the roots and shoots. They stimulate rooting, as well as the active growth of the main shoot. Auxin promotes the formation of roots in leaf and stem cuttings. Gibberellin is responsible for the growth of the stem, so it is called growth hormone. It is formed mainly in the leaves and sometimes in the roots. Cytokinin regulates the establishment and growth of the kidneys. Lateral shoot growth is associated with cytokinins. Ethylene is responsible for the ripening of the fruit, as well as for preparing for the winter period. It should be noted that in some cases, ethylene can also have a stimulating effect on plant growth. But as a whole, ethylene is an aging hormone. After all, any maturation always turns into aging [13].

Synthetic growth regulators exert their action with the help of the endogenous level of natural hormones, thus contributing to modifying growth and development in the right degree and in the desired direction [9].

Plant growth regulators make a significant contribution to obtaining high yields in modern agricultural technologies, especially in adverse weather conditions. The use of these drugs is especially important in the cultivation of cereals, legumes, because the duration of flowering and fruit formation is long 
enough, which in turn affects the quality of seeds. In addition, plant growth regulators are of great interest in the cultivation of agricultural crops, the harvesting of which under production conditions is difficult due to heavy lodging, uneven ripening and grain losses during late harvesting [6].

Plant growth regulators allow you to weaken or strengthen the characteristics and properties of plants within the normal reaction set by the genotype and heredity.

One need not forget the important thing: growth regulators should be used strictly in the designated concentrations, which are listed on the packaging. Excessive use of growth drugs can lead to a sharp decrease in the efficiency, inhibition of plants and their death.

The creation of new physiologically active substances, regulators of growth and development of plants, and their study is of great importance. In general, all growth regulators are highly specific active compounds that are sensitive even to the varietal differences of plants. The physiological effect of regulators depends on the timing and methods of use, the dose of the drug, meteorological conditions and the state of the plants [11].

Growth regulators in foreign countries were used to solve certain tasks set before the formation of agricultural products the acquisition of a given quality and quantity of agricultural products. In such industries as fruit growing, ornamental horticulture, and vegetable growing, the use of growth regulators is considered to be the most important agrotechnical method. In general, these growth regulators process $50-80 \%$ of crops [14].

The creation of new ultra-ripening soybean varieties of the northern ecotype made it possible to cultivate it in the Central Non-Black Earth region, where this crop is introduced. For the conditions of the Chuvash Republic, soybean is a fairly new culture, which does not always manage to form high quality seeds. The study of growth regulators, allowing to reduce the effect of adverse environmental factors on the normal growth and development of soybean plants, as well as their productivity is very relevant today.

\section{A. Research objective}

The aim of our research was to study the effect of Ekopin, Lignohumate and Seedlings growth regulators on the formation of yield in the conditions of the Chuvash Republic.

\section{MATERIALS AND RESEARCH METHODS}

Studies were conducted in 2015-2017 at the collection site of the Department of Agriculture, Plant Growing, Breeding and Seed Production at the Student Scientific and Production Center. The soils of the plot are light gray forest, characterized by a low content of humus, increased phosphorus and medium potassium, slightly acid reaction of the soil environment.

The experiments were laid out as follows:

1. Control - seed treatment with clean water before sowing.
2. Ekopin - processing of soybean seeds before sowing.

3. Lignohumate - processing of soybean seeds before sowing.

4. Seedling - processing of soybean seeds before sowing.

The total area of the plot was $1.2 \mathrm{~m}^{2}$. Sowing method ordinary with a seeding depth of $4 \mathrm{~cm}$. The seeding rate of soybean seeds was 600 thousand units / ha. The repetition of the experience is sixfold.

The vegetation period of 2015 was characterized by a rather high temperature and a lack of moisture at the beginning of the growing season, elevated temperature and excess rainfall in the middle. In 2016, there was a hot summer with moderate precipitation. 2017 was characterized by moderately warm summer and excessive rainfall during the growing season of soybean plants.

The object of research was the SibNIIK 315 soybean variety, the studied growth regulators Ekopin, Lignohumate and Seedlings were used for soaking seeds before sowing, the doses and methods of using the preparations were selected according to the recommendations. The control version was soaked in water.

The trials establishment, observations and counts were carried out according to the methodology of the State Commission for the varietal testing of field crops. Agrotechnology in the experience was common for the zone.

\section{RESEARCH RESULTS AND DISCUSSION}

The use of growth regulators for presowing treatment of seeds contributed to the change in the biometric indicators of soybean plants (Table 1).

Seed treatment with growth regulators had no significant effect on the field germination of soybean plants in 2015. In the control, it was $69.2 \%$; in seed treatment with the preparations Ekopin, Lignohumate and Seedling, germination was $75.5 \%$, $74.8 \%$, and $70.6 \%$, respectively. The effectiveness of drugs was more significant in the dry 2016. So the processing of soybean seeds by Ekopin allowed to increase the germination rate by $22.4 \%$, Lignohumate - by $21.9 \%$ compared with the control. The germination of soybean seeds in these variants was 78.6 and $78.3 \%$, respectively.

Ekopin and Lignohumate growth regulators contributed to the emergence of seedlings 2-4 days earlier than control, flowering began 3-4 days earlier and, in general, their use contributed to accelerating the ripening of soybeans. At the same time the vegetation period time was reduced by 5-7 days compared with the control. On the average, the growing season in the control variant was 106 days, in the variant with the use of Ekopin - 97 days, Lignohumate - 101 days, Seedlings - 103 days.

Presowing treatment of soybean seeds with growth regulators contributed to an increase in the safety of plants. The seedling preparation contributed only to an insignificant 
increase in preservation, while the preservation of soybean plants in the variants with Ekopin and Lignohumate treatment respectively increased by 4.5 and $4 \%$ compared to the control.

TABLE 1 SEED GERMINATION AND PRESERVATION OF SOYBEAN PLANTS FOR HARVESTING (AVERAGE FOR 2015-2017)

\begin{tabular}{|c|c|c|}
\hline Options & $\begin{array}{c}\text { Germination of } \\
\text { soybean,\% }\end{array}$ & $\begin{array}{c}\text { Safety of soybean } \\
\text { plants, \% }\end{array}$ \\
\hline Control & 64.5 & 86.8 \\
\hline Ekopin & 76.3 & 90.7 \\
\hline Lignohumate & 76.2 & 90.3 \\
\hline Seedling & 74.6 & 88.7 \\
\hline
\end{tabular}

The height of soybean plants differed little in terms of options. On average, it was $68.61 \mathrm{~cm}$ over the years of research in the control group, in the variants with Ekopin, Lignohumate and Seedlings $-72.52 \mathrm{~cm}, 69.35 \mathrm{~cm}$ and $71.8 \mathrm{~cm}$, respectively (table 2).

The height of the formation of the bottom bean on average for three years of research was $11.3-12.29 \mathrm{~cm}$. The highest height of attachment of the lower bean was recorded on soybean plants, the seeds of which were treated with Lignohumate - 12, $29 \mathrm{~cm}$. The number of productive beans formed by soybean plants in 2015 turned out to be more than in the conditions of 2016 and 2017.

TABLE II SOYBEAN PLANT BIOMETRICS (AVERAGE FOR 2015-2017)

\begin{tabular}{|c|c|c|c|c|}
\hline Option & $\begin{array}{c}\text { Plant } \\
\text { height, } \\
\text { cm }\end{array}$ & $\begin{array}{c}\text { Height } \\
\text { to the } \\
\text { first } \\
\text { bean, cm }\end{array}$ & $\begin{array}{c}\text { The } \\
\text { number } \\
\text { of } \\
\text { branche } \\
\text { s, pieces }\end{array}$ & $\begin{array}{c}\text { The percentage } \\
\text { of productive } \\
\text { beans }\end{array}$ \\
\hline Control & 68.61 & 11.47 & 3.58 & 94.28 \\
\hline Ekopin & 72.52 & 11.35 & 4.33 & 95.01 \\
\hline Lignohumate & 69.35 & 12.29 & 4.14 & 94.81 \\
\hline Seedling & 71.8 & 11.54 & 3.6 & 96.82 \\
\hline
\end{tabular}

The weather conditions developing during the growing season of plants had a significant impact on the structure of the soybean crop. Thus, in the conditions of 2015, on the control variant, an average of 32.6 beans was formed on a soybean plant, the average seed weight per plant was $6.9 \mathrm{~g}$ (Table 3 ).

Pre-sowing treatment of soybean seeds with Ekopin and Lignohumate preparations allowed increasing the number of beans to 41.1 and $43.8 \mathrm{pcs}$, and the weight of seeds per plant to 11.1 and $12.6 \mathrm{~g}$, respectively.

Soybean plants formed a larger number of branches in 2016, compared with other years of research. This contributed to an increase in yield structure indicators. In the control variant, an average of 89.7 beans was formed on a soybean plant; the seed mass per plant was $28.1 \mathrm{~g}$.
The treatment of seed with the preparations Ekopin and Lignohumate allowed increasing the number of beans per plant to 91.4 and 105.3 pieces, and the seed weight from one plant to 26.5 and $30.1 \mathrm{~g}$, respectively.

As for 2017, the largest number of beans per plant was obtained in the variant with the use of the Ekopin growth regulator - an average of 99.0 pcs. The mass of seeds from plants in this variant also turned out to be the highest for all the years of research $-33.3 \mathrm{~g}$.

Lignohumate and Seedlings preparations in the conditions of 2017 according to these indicators slightly exceeded the control variant.

Such an indicator as the mass of 1000 seeds had an inverse relationship - more completed seeds for each of the options were obtained in 2015.

On average, over the years of research, more accomplished and larger seeds were obtained on variants using growth Ekopin and Lignohumate regulators - 181.4 and $181.5 \mathrm{~g}$, respectively.

TABLE III THE INFLUENCE OF GROWTH REGULATORS ON THE ELEMENTS OF THE CROP STRUCTURE, 2015-2017

\begin{tabular}{|c|c|c|c|c|}
\hline Option & $\begin{array}{c}\text { The } \\
\text { number of } \\
\text { beans per } \\
\text { plant, } \\
\text { pieces }\end{array}$ & $\begin{array}{c}\text { The } \\
\text { number of } \\
\text { seeds per } \\
\text { plant, } \\
\text { pieces }\end{array}$ & $\begin{array}{c}\text { The mass } \\
\text { of seeds } \\
\text { per plant, } \\
\text { g }\end{array}$ & $\begin{array}{c}\text { Weight } \\
\text { of 1000 } \\
\text { seeds, g }\end{array}$ \\
\hline Control & 56.73 & 91.53 & 18.31 & 163.03 \\
\hline Ekopin & 77.18 & 130.44 & 23.63 & 181.36 \\
\hline Lignohumate & 63.62 & 110.08 & 20.08 & 181.45 \\
\hline Seedling & 62.77 & 110.23 & 19.48 & 177.13 \\
\hline
\end{tabular}

The growth regulators studied had a significant impact on soybean productivity.

For all three years of research, it was found that the treatment of seed contributed to a significant increase in soybean yield.

In 2015, seed treatment with Ekopin increased the yield of soybeans by $16 \%$, Lignohumate - by $23.4 \%$, and the Seedling by $1.1 \%$. In 2016 , the maximum yield was obtained in the variant with seed treatment with Ekopin and amounted to 3.31 $\mathrm{t} / \mathrm{ha}$, which is $28.3 \%$ higher than in the control variant.

The use of the drug Lignohumate for pre-sowing treatment of soybean seeds in 2017 contributed to an increase in its yield by $22.5 \%$ compared with the control $-4.63 \mathrm{t} / \mathrm{ha}$.

On the average, over three years of research, the highest yield of soybean was obtained in the variant using the growth regulator Lignohumate $-4.63 \mathrm{t} / \mathrm{ha}$. A little less - $4.39 \mathrm{t} / \mathrm{ha}$ obtained in the variant with the use of Ekopin.

The attained results indicate the effectiveness of pre-sowing treatment of soybean seeds with Ekopin and Lignohumate growth regulators. 
TABLE IV SOYBEAN YIELDS FOR SEED TREATMENT WITH GROWTH REGULATORS

\begin{tabular}{|c|c|c|c|c|c|c|}
\hline \multirow{2}{*}{ Option } & \multicolumn{2}{|c|}{$\mathbf{2 0 1 5}$} & \multicolumn{2}{|c|}{$\mathbf{2 0 1 6}$} & \multicolumn{2}{|c|}{$\mathbf{2 0 1 7}$} \\
\cline { 2 - 7 } & $\begin{array}{c}t / h \\
a\end{array}$ & $\begin{array}{c}\text { Deviatio } \\
\text { f from } \\
\text { control, } \\
t / h a\end{array}$ & $\begin{array}{c}t / h \\
a\end{array}$ & $\begin{array}{c}\text { Deviatio } \\
\text { from } \\
\text { control, } \\
t / h a\end{array}$ & $\begin{array}{c}\text { Deviatio } \\
n \text { from } \\
a\end{array}$ & $\begin{array}{c}\text { control, } \\
t / h a\end{array}$ \\
\hline Control & 3.6 & - & 2.6 & - & 3.8 & - \\
\hline Ekopin & 4.1 & 0.57 & 3.3 & 0.73 & 4.4 & 0.61 \\
\hline $\begin{array}{c}\text { Lignohuma } \\
\text { te }\end{array}$ & 4.4 & 0.83 & 3.2 & 0.6 & 4.6 & 0.85 \\
\hline Seedling & 3.6 & 0.04 & 3.2 & 0.62 & 4.3 & 0.53 \\
\hline HCP05 & & 0.16 & & 0.23 & & 0.14 \\
\hline
\end{tabular}

\section{CONCLUSION}

1. Presowing seed soaking in Ekopin and Lignohumate growth regulators had a significant impact on the field germination of soybean plants - the increase in control was 18.3 and $18.1 \%$, respectively.

2. The use of growth regulators contributed to the reduction of the growing season of plants by an average of 5-7 days compared with the control.

3. The differences between the control and the variant with the growth regulator treatment are not significant in terms of plant height and height of attachment of the lower bean, as well as the number of branches. Plants in the variant with the use of Ekopin formed a larger number of branches. The percentage of productive beans on plants was almost the same in all studied variants.

4. The growth regulators under study had an effect on soybean productivity. They have contributed to a significant increase in yield for all the years of research. Thus, the maximum yield was obtained in the variant with Lignohumate seed treatment $-4.63 \mathrm{t} /$ ha, a little less $-4.39 \mathrm{t} / \mathrm{ha}$ - in the variant with the use of Ekopin.

\section{References}

[1] H.I. Mohamed, H.H. Latif, "Improvement of drought tolerance of soybean plants by using methyl jasmonate", Physiology and Molecular Biology of Plants, 2017, Vol. 23, No. 3, pp. 545-556.
[2] L.V. Eliseeva, O.V.Kayukova. "The effect of presowing seed treatment with growth regulators on the productivity of soybean", Biologization of agriculture - the basis of the reproduction of soil fertility, 2018, pp. 67-70.

[3] M. Zhang, Z. Zhai, X. Tian, L.Duan, Z. Li, "Brassinolide alleviated the adverse effect of water deficits on photosynthesis and the antioxidant of soybean (Glycine Max L.)", Plant Growth Regulation, 2008, Vol. 56, No. 3, pp. 257-264.

[4] L.V. Eliseeva, O.V. Kayukova, O.P. Nesterova. "The influence of growth regulators on the productivity of soybean in the conditions of the Chuvash Republic", "Bulletin of Mari State University. Ser. Agricultural science. Economic Sciences", No. 3, 2018, pp. 22-26.

[5] W. Chen, D. Zheng, N. Feng, T. Liu, Y. Liu, S. Gong, H. Cui, H. Xiang, "The effects of gibberellins and mepiquat chloride on nitrogenase activity in bradyrhizobium japonicum", Acta Physiologiae Plantarum, 2015, Vol. 37 , No. 1 .

[6] W. Qingxiang, Z .Feng, D.L.Smith, "Application of ga3 and kinetin to improve corn and soybean seedling emergence at low temperature", Environmental and Experimental Botany, 1996,Vol. 36, No. 4, pp. $377-$ 383.

[7] H. Li, T. Wu, Y. Deng, S. Subramanian, O. Yu, "Misexpression of mir482, mir1512, and mir1515 increases soybean nodulation", Plant Physiology, 2010, Vol. 153, No. 4, pp. 1759-1770.

[8] W.T. Teixeira, R.C. Umburanas, D.D. Neto, E.B. Fagan, L.H. Soares, K Reichardt, "Foliar and seed application of amino acids affects the antioxidant metabolism of the soybean crop", Frontiers in Plant Science, 2017, Vol. 8, p. 327.

[9] O.S. Correa, M.S. Montecchia, M.F. Berti, M.C.F. Ferrari, N.L. Pucheu, N.L. Kerber, A.F. García, "Bacillus amyloliquefaciens bnm122, a potential microbial biocontrol agent applied on soybean seeds, causes a minor impact on rhizosphere and soil microbial communities", Applied Soil Ecology, 2009, Vol. 41, No. 2, pp. 185-194.

[10] M.G. Dawood, S.R. El-Lethy, S. Mervat, "Role of methanol and yeast in improving growth, yield, nutritive value and antioxidants of soybean", World Applied Sciences Journal, 2013, Vol. 26, No. 1, pp. 6-14.

[11] M.R. Dadnia "Effects of bacterial strains on pod formation,yield,protein and oil content in soybean (Glycine Max L.)", Research on Crops, 2011, Vol. 12, No. 2, pp. 421-424.

[12] A. Argaw, "Evaluation of co-inoculation of bradyrhizobium japonicum and phosphate solubilizing pseudomonas spp. Effect on soybean (Glycine Max L. (Merr.)) in assossa area", Journal of Agricultural Science and Technology, 2012, Vol. 14. No. 1, pp. 213-224.

[13] M.M. Tahir, M.K. Abbasi, N. Rahim, A. Khaliq, M.H. Kazmi, "Effect of rhizobium inoculation and $n p$ fertilization on growth, yield and nodulation of soybean (glycine max 1.) In the sub-humid hilly region of rawalakot azad jammu and kashmir, pakistan", African Journal of Biotechnology, 2009, Vol. 8, No. 22, pp. 6191-6200.

[14] P. Nimnoi, N. Pongsilp, S. Lumyong "CO-Inoculation of soybean (glycine max) with actinomycetes and bradyrhizobium japonicum enhances plant growth, nitrogenase activity and plant nutrition", Journal of Plant Nutrition", 2014, Vol. 37, No. 3, pp. 432-446.

[15] E.V. Zolotareva, V.V. Logachev "Prospects for the use of growth regulators on soybeans in the Khabarovsk Territory", Achievements of science and technology of agriculture, 2010, No. 6, pp. 47-48. 